\title{
Alkaloid-rich fraction of Himatanthus lancifolius contains anti-tumor agents against leukemic cells
}

\author{
Melissa Pires de Lima1, Luciana Farhat Hilst ${ }^{1}$, Fernanda Vanessa Rechinbach Mattana ${ }^{1}$, Cid \\ Aimbiré de Moraes Santos², Almeriane Maria Weffort-Santos ${ }^{1,2, *}$
}

\begin{abstract}
${ }^{1}$ Laboratory of Hematology, Department of Medical Pathology, Federal University of Paraná, ${ }^{2}$ Laboratory of Pharmacognosy,
\end{abstract} Department of Pharmacy, Federal University of Paraná

\begin{abstract}
The effects of the alkaloid-rich fraction of Himatanthus lancifolius (Müll. Arg) Woodson on normal marrow cells and leukemic cell lines were investigated. After $48 \mathrm{~h}$ exposure, the proliferation assay showed significant cell growth inhibition for Daudi $(0.1-10 \mu \mathrm{g} / \mathrm{mL}), \mathrm{K}-562(1-10 \mu \mathrm{g} / \mathrm{mL})$, and REH cells $(10-100 \mu \mathrm{g} / \mathrm{mL})$, yet was inert for normal marrow cells. A similar inhibition profile was observed in clonogenic assays. This alkaloid-rich fraction, in which uleine is the main compound, showed no signs of toxicity to any cells up to $10 \mu \mathrm{g} / \mathrm{mL}$. Cell feature analyses after induction of differentiation showed maintenance of the initial phenotype. Flow cytometric expression of Annexin-V and 7-AAD in K-562 and Daudi cells has indicated that the cells were not undergoing apoptosis or necrosis, suggesting cytostatic activity for tumor cells.
\end{abstract}

Uniterms: Apocynaceae. Cell proliferation. Himatanthus lancifolius. Indole alkaloids. Leukemia. Plant extract.

Os efeitos da fração rica em alcalóides indólicos de Himatanthus lancifolius (Müll. Arg) Woodson sobre células normais de medula óssea e linhagens celulares leucêmicas foram investigados. Após 48 horas de exposição, os ensaios de proliferação demonstraram efeitos inibitórios significativos para as linhagens Daudi $(0,1-10 \mu \mathrm{g} / \mathrm{mL}), \mathrm{K}-562(1-10 \mu \mathrm{g} / \mathrm{mL})$ e REH $(10-100 \mu \mathrm{g} / \mathrm{mL})$, enquanto mostrou-se inerte sobre células normais de medula óssea. Os perfis de inibição se repetiram nos ensaios clonogênicos. A fração rica em alcalóides, na qual a uleína é a substância majoritária, não demonstrou toxicidade até a dose de $10 \mu \mathrm{g} / \mathrm{mL}$ para nenhuma das células incluídas no estudo. Da mesma forma, não se observou influência dessa fração sobre a diferenciação celular dessas linhagens, mas manutenção de seu estado maturacional inicial. O conjunto de dados descritos associado à baixa co-expressão de anexina-V e 7-AAD sugerem que esta fração exerce atividade citostática para células tumorais.

Unitermos: Apocynaceae. Proliferação celular. Himatanthus lancifolius/farmacognosia. Alcalóides indólicos. Leucemia. Extrato vegetal.

\section{INTRODUCTION}

The hematopoietic system functions throughout the life of the animal to continually supply the mature cells of the myeloid and lymphoid lineages derived from the hematopoietic stem cells by a hierarchical system of progenitors with varying capacities for cell replication and increasing differentiation potentialities. These actions

\footnotetext{
*Correspondence: A. M. Weffort-Santos. Laboratory of Hematology, Department of Medical Pathology, Federal University of Paraná. Av. Prefeito Lothario Meissner, n.632 - Jd Botânico - 80210-070 - Curitiba - PR, Brazil. E-mail: almeriane@ufpr.br
}

can be monitored by assays that are based on the ability of progenitor cells to proliferate in vitro in response to growth factors and cytokines, as occurs physiologically in vivo.

Leukemia is a broad term covering a spectrum of malignancies of the hematopoietic system causing high death rates worldwide. In Brazil alone, according to the National Institute of Cancer (INCA), around ten thousand new cases were expected for 2008, accounting for nearly $3 \%$ of the total number of new diagnosed neoplasms. They are clinically and pathologically split into acute and chronic forms, characterized by an increase in immature blood cells or an excessive build up of relatively mature 
but abnormal cells, respectively. Whatever is the case, the malignant cell crowding renders the bone marrow unable to produce healthy blood cells to aid body metabolism against anemia, infections, or coagulation disorders.

Given its nature, leukemia continues to present formidable treatment challenges as there is not yet a "standard approach" that reliably and safely cures the majority of patients suffering from these disorders. A considerable portion of anti-tumor agents currently used in the clinic are of natural origin. In fact, half of all anti-cancer drugs approved internationally between the 1940s and 2006 were either natural products or their derivatives and were developed on the basis of knowledge gained from small molecules or macromolecules that exist in nature (Efferth et al., 2007).

Naturally occurring drugs that are part of the arsenal in the war against cancer include several indole Vinca alkaloids (vincristine, vinblastine, vindesine, vinorelbine), taxanes (paclitaxel, docetaxel), podophyllotoxin and its derivatives (etoposide, teniposide), camptothecin and its derivatives (topothecan, irinothecan), and anthracyclines (doxorubicin, daunorubicin, epirubicin, idarubicin) amongst others.

Plants of the genus Himatanthus (Apocynaceae) are used in South American folk medicine for several conditions ranging from snakebites, tumors, arthritis to gastritis. Activities against malaria (Milliken, 1997), cutaneous leishmaniasis, and trypanosomiasis (Castillo et al., 2007) have been reported as well as anti-inflammatory and analgesic properties (Miranda et al., 2000; Vanderlei, Souzabrito, 1986).

Himatanthus lancifolius (Muell. Arg.) Woodson is a plant widely distributed in Brazil and officially described in the Brazilian Pharmacopoeia I (Santos, 1926). Popularly known as "agoniada", its dried stem barks are used in folk medicine for treating ulcers, skin conditions, as a febrifuge, emmenagogue, purgative, against asthma, syphilis, for regularizing menstrual cycles, and also for coping with conception by stimulating uterine contractions (Corrêa et al., 1998).

Many activities for the alkaloid-rich fraction (ARF) obtained from the H. lancifolius barks, rich in indole alkaloids such as uleine and demethoxyaspidospermine (França et al., 2000), have been reported. First, it has demonstrated a broad-spectrum of in vitro antimicrobial activity for pathogenic microorganisms (Souza et al., 2004). A gastroprotective effect of this fraction has been described (Baggio et al., 2005), supporting the popular usage of the plant as an anti-ulcer agent. In addition, this fraction was able to alter vascular and non-vascular smooth muscle responsiveness (Rattmann et al., 2005). Recently, we have shown that uleine, its major alkaloid component, was able to interfere with human leukocyte functions as it significantly inhibited the migration of casein-induced granulocytes and their adhesion to fibronectin and vitronectin, confirming its usefulness in inflammatory conditions (Nardin et al., 2008).

As some indole alkaloids recently isolated have shown antileukemic effects (Gan et al., 2006; Zhang et al., 2007), the aim of this study was to investigate the effects of ARF extracted from $H$. lancifolius barks on normal and leukemic cells. In the present study, we describe for the first time that this fraction possesses a cytostatic action restricted to leukemic cells.

\section{MATERIAL AND METHODS}

\section{Plant Material}

Himatanthus lancifolius (Muell. Arg.) Woodson stem barks were purchased in the city of São Paulo, Brazil, in February 2003, and identified according to the Brazilian Pharmacopoeia I description (Santos, 1926), and by macro and microscopic comparisons with an authentic sample of the Laboratory of Pharmacognosy, Department of Pharmacy, Federal University of Paraná, Curitiba, Brazil, which holds a voucher specimen deposited under Protocol No. HLF-9.

\section{Alkaloid-rich fraction and treatment solution}

The procedures undertaken for obtaining the alkaloid-rich fraction along with its chemical characterization have been essentially described elsewhere (Baggio et al., 2005; Rattmann et al., 2005; Nardin et al., 2008). ARF stock solution at $1 \mathrm{mg} / \mathrm{mL}$ was prepared by diluting it directly into RPMI 1640 (Himedia Laboratories; Mumbal, India) or IMDM (Gibco; Paisley, UK) medium supplemented with inactivated-sterile fetal calf serum (FCS - Cultilab; Campinas, São Paulo, BR). After sterilization through a 0.22 um pore size filter, $1 \mathrm{~mL}$ aliquots were stored at minus $25^{\circ} \mathrm{C}$. Final concentrations $(0.1$ to $1000 \mu \mathrm{g} / \mathrm{mL})$ were obtained by thawing and diluting the stock solution in the appropriate culture medium immediately prior to the experiments.

\section{Cell lines}

The K-562 and Daudi leukemia cell lines were purchased from the Rio de Janeiro Cell Bank, Federal University of Rio de Janeiro (RJBC; Rio de Janeiro, Brazil). REH lymphoid cells were kindly provided by Dr. B. C. 
Figueiredo, Centro de Genética Molecular e Pesquisa do Câncer em Crianças (CEGEMPAC; Curitiba, Brazil). The cell lines were kept at $37^{\circ} \mathrm{C}$ in $5 \% \mathrm{CO}_{2}$ humidified atmosphere in RPMI 1640 medium supplemented with FCS (10 and $20 \%$ for myeloid and for lymphoid cell lines, respectively), 2 mM L-glutamine (G-8540 Sigma; St Louis, MO, USA), 100 IU/mL G-penicillin (P-3032 Sigma; St Louis, MO, USA), 3 g/L sodium bicarbonate (S-5761 Sigma; $\mathrm{St}$ Louis, MO, USA) and $50 \mu \mathrm{g} / \mathrm{mL}$ streptomycin sulphate (S-6501 Sigma; St Louis, MO, USA). Twice a week, the cells were split at $10^{5}$ cells $/ \mathrm{mL}$. REH cells were subcultured once a week at $10^{5}$ cells $/ \mathrm{mL}$. For the experiments, all cell lines were harvested at the exponential growth phase and checked for viability using the Trypan blue assay $[0.4 \%$ Trypan blue - 11732; Merck, Germany - in Dulbecco's phosphate buffered saline (PBS)]. For the experiments, the number of viable cells always exceeded $95 \%$.

\section{Mouse bone marrow cells}

The protocol used in this study for mouse bone marrow cells was previously approved by the Animal Experiment Ethics Committee of the Biological Sciences Sector of the Federal University of Paraná (Protocol 23075.028831/2008-33). Bone marrow cells were obtained from femora and tibia of 4-5 week-old female C57/BL6 mice. The mononuclear fraction (MNC) was isolated from the interface using density gradient centrifugation on a Ficoll-Paque ${ }^{\mathrm{TM}}$ PLUS device (Amersham Biosciences; Little Chalfont, UK). After washing twice with PBS, MNC was resuspended in IMDM supplemented with sodium bicarbonate, L-glutamine, $10 \%$ fetal calf serum, and antibiotics as for RPMI 1640 medium.

\section{Cell viability and toxicity}

Toxic effects of the extract and all solutions used in this study on normal and leukemic cells were evaluated for all doses assayed using the trypan blue exclusion test. Viability was taken as the percentage of cells not incorporating the stain, counted in a hemocytometer after directly diluting the cell suspension with $0.4 \%$ Trypan blue solution.

\section{Proliferation assays}

For each cell line, aliquots of $100 \mu \mathrm{L}$ of cell suspensions containing $10^{5}$ cells in complete RMPI 1640 medium were distributed in flat-bottomed 96-well culture dishes (TPP; Switzerland) and left for 24 hours at $37{ }^{\circ} \mathrm{C}$ in a $5 \% \mathrm{CO}_{2}$ incubator. ARF solution was then added to give final concentrations ranging from 0.1 to $1000 \mu \mathrm{g} / \mathrm{mL}$ in a $200 \mu \mathrm{L}$ final volume/well for 48 hours. For bone marrow cells, a $100 \mu \mathrm{L}$ containing $2 \times 10^{5} \mathrm{MNC}$ in complete IMDM medium were seeded for each well and ARF was simultaneously added ( 0.1 to $1000 \mu \mathrm{g} / \mathrm{mL})$ in a $200 \mu \mathrm{L}$ final volume/well for a week. The number of cells recovered was evaluated on a hemocytometer. Each experiment was performed in triplicate and the results are expressed as the mean cell number recovered \pm standard error of mean (SEM) after incubation of at least three independent experiments, each one run in triplicate.

\section{Differentiation assay}

Hemin chloride 40 uM (H-5533 Sigma; St Louis, MO, USA) and theophylline $7 \mathrm{mM}$ (T-1633 Sigma; St Louis, MO, USA) were used as positive differentiation inducers for K-562 (Huo et al., 2006) and Daudi (Sandlund et al., 1993) cell lines, respectively. Triplicates of cell suspension of each cell line $\left(10^{6} \mathrm{cell} / \mathrm{mL}\right)$ in complete RMPI 1640 medium containing ARF solution to give final concentrations ranging from 0.1 to $100 \mu \mathrm{g} / \mathrm{mL}$, or the required concentration of the cell differentiation inducers, in a $1000 \mu \mathrm{L}$ final volume/well were distributed in 24-well culture plates (TPP; Switzerland) and incubated for 7 days at $37^{\circ} \mathrm{C}$ in $5 \% \mathrm{CO}_{2}$. The morphology of the cultured cells was observed by immersion oil microscopy in cytospin preparations stained with May-Grunwald-Giemsa. Cell photos were documented using the Image Pro Plus software, version 3.0.01.00 for Windows 3.0.

\section{Colony-Forming assays}

The clonogenic potential of K-562 cells was assayed by counting colonies grown in the commercial viscous medium MethoCult ${ }^{\mathrm{TM}}$ (StemCell Technologies Inc.; Vancouver, CA) supplemented with Stem Cell Factor $(50 \mathrm{ng} / \mathrm{mL})$, GM-CSF (10 ng/mL)'IL-3 (10 ng/mL), and erythropoietin $(3 \mathrm{IU} / \mathrm{mL})$ recombinant human cytokines. The cells were first washed with PBS, suspended in IMDM medium supplemented with $10 \%$ FCS, and the concentration adjusted to a density of $2 \times 10^{5}$ cells $/ \mathrm{mL}$. $10^{3} \mathrm{~K}-562$ cells were added to $1 \mathrm{~mL}$ of MethoCult. The mixture was plated in three aliquots of $0.3 \mathrm{~mL}$ each, into 24-well plastic culture dishes (TPP, Switzerland). For Daudi cells $\left(10^{4}\right.$ cells $\left./ \mathrm{mL}\right)$, the plating medium was composed of RPMI 1640 supplemented with $30 \%$ of FCS, $10 \%$ of Cariotype Medium (Cultilab; Campinas, $\mathrm{BR}$ ) in a final volume of $3 \mathrm{~mL}$ plating mixture. A $150 \mu \mathrm{L}$ volume of molten agar at 3.3\% (A-9915 Sigma; St Louis, MO, USA) was added to the mixture and $1 \mathrm{~mL} /$ dish 
was immediately transferred to $40 \times 11 \mathrm{~mm}$ plastic tissue culture Petri dishes (TPP, Switzerland). ARF (0.1-100 $\mu \mathrm{g} / \mathrm{mL}$ ) was added to the plating medium immediately before the cells. The dishes were incubated at $37^{\circ} \mathrm{C}$ in a fully humidified atmosphere supplemented with $5 \% \mathrm{CO}_{2}$ in air. After 7 days, the colonies were scored by direct observation under an inverted microscope. Each independent experiment was performed in triplicate and the results are expressed as the mean colony number \pm SEM.

\section{Annexin- $V$ and 7-AAD co-expression by flow cytometry}

After 24 hours of subculture at $37^{\circ} \mathrm{C}, \mathrm{K}-562$ and Daudi cells $\left(10^{6} / \mathrm{mL}\right)$ were treated with 10 or $100 \mu \mathrm{g} / \mathrm{mL}$ of ARF and further incubated for 48 hours. The cells were then harvested and washed with cold PBS by spinning at $400 \mathrm{~g}$ for $5 \mathrm{~min}$ at $4{ }^{\circ} \mathrm{C}$. Cells $\left(10^{5}\right)$ were resuspended in $100 \mu \mathrm{l}$ of $1 \mathrm{X}$ binding buffer and stained with $2 \mu \mathrm{L}$ Annexin V-FITC (BD/PharMingen; San Diego, California, USA) and $5 \mu \mathrm{L}$ 7-aminoactinomycin D (7-AAD; BD/ PharMingen; San Diego, California, USA) in the dark for $15 \mathrm{~min}$ at room temperature. Another $400 \mathrm{ul}$ of $1 \mathrm{X}$ binding buffer were added at the end of staining period. Cells without exposure to the extract served as controls. In all experiments, fluorescence was measured using appropriate band pass filters for FITC (FLH-1) and 7-AAD (FLH-3) absorption in a BD FACS Calibur flow cytometer (Becton Dickinson; San Jose, California, USA) equipped with an argon laser tuned at $488 \mathrm{~nm}$. For analyses, at least $10^{4}$ events were acquired in the gated populations. Data were analysed using the WinMDI 2.8 software, and the results are expressed as the mean percentage of positive cells for each population from three independent experiments.

\section{Statistical analysis}

Where applicable, significant differences $(p \leq 0.05)$ between treated and control groups were determined using the Student's $t$-test for comparison of two means, or Analyses of Variance - one way (ANOVA) followed by Tukey's HSD $-\alpha=0.05$ for multiple comparisons.

\section{RESULTS}

Treatment of the cell lines with ARF at doses ranging from 0.1 to $100 \mu \mathrm{g} / \mathrm{mL}$ for 48 hours after the setting period showed significant dose-dependent inhibition of cell growth for K-562, Daudi, and REH cells (Figure 1). No cells of any lineage could be recovered from cultures in which the final concentration of ARF was $1000 \mu \mathrm{g} / \mathrm{mL}$.

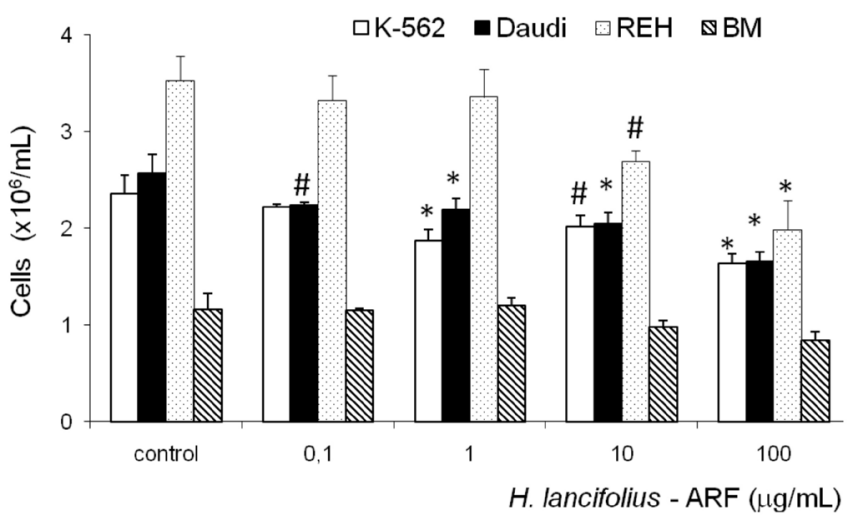

FIGURE 1 - Dose-dependent inhibition of H. lancifolius alkaloid-rich fraction in growth of leukemic and normal cells. Exponentially growing cells were treated with the indicated doses of ARF for $48 \mathrm{~h}$, at $37^{\circ} \mathrm{C}$. Each bar represents the number of recovered cells \pm EPM from at least 3 experiments, each performed in triplicate. [\#] $p<0.05 ;\left[{ }^{*}\right] p<0.001$.

The distinct proliferation behaviour of each cell line after ARF exposure may be better visualized in Figure 2. $\mathrm{REH}$ cells were the most affected, with an $\mathrm{IC}_{50}$ value of $123.73 \mu \mathrm{g} / \mathrm{mL}$, followed by Daudi $\left(\mathrm{IC}_{50}=235.10 \mu \mathrm{g} / \mathrm{mL}\right)$ and $\mathrm{K}-562$ cells $\left(\mathrm{IC}_{50}=289.55 \mu \mathrm{g} / \mathrm{mL}\right)$.

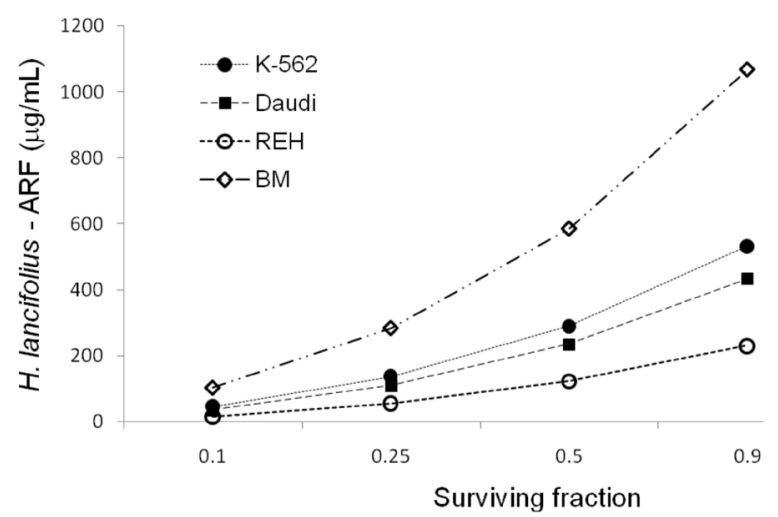

FIGURE 2 - Effect of alkaloid-rich fraction of $H$. lancifolius on cell survival. The indicated cell lines were plated out in the presence of the H. lancifolius ARF. Each point represents the surviving fraction of leukemic cell lines recovered after exposure for $48 \mathrm{~h}$ at $37^{\circ} \mathrm{C}$. The 0.5 point represents the $\mathrm{IC}_{50}$ for each cell line.

In contrast, $\mathrm{ARF}$ had little effect on normal marrow cell proliferation, for which the $\mathrm{IC}_{50}$ was $584.48 \mu \mathrm{g} / \mathrm{mL}$. Interestingly and worthy of note, no cell toxicity of the ARF fraction was observed up to $10 \mu \mathrm{g} / \mathrm{mL}$ (Figure 3). In this frame, although a small but significant toxicity was observed for the K-562, REH, and Daudi cells at $100 \mu \mathrm{g} / \mathrm{mL}$, $88.3 \pm 0.5,86.5 \pm 2.8$, and $79.8 \pm 2.6 \%$ of the cells still remained viable, respectively ( $p<0.001$ for all; $\mathrm{n}=3-5$ ). 


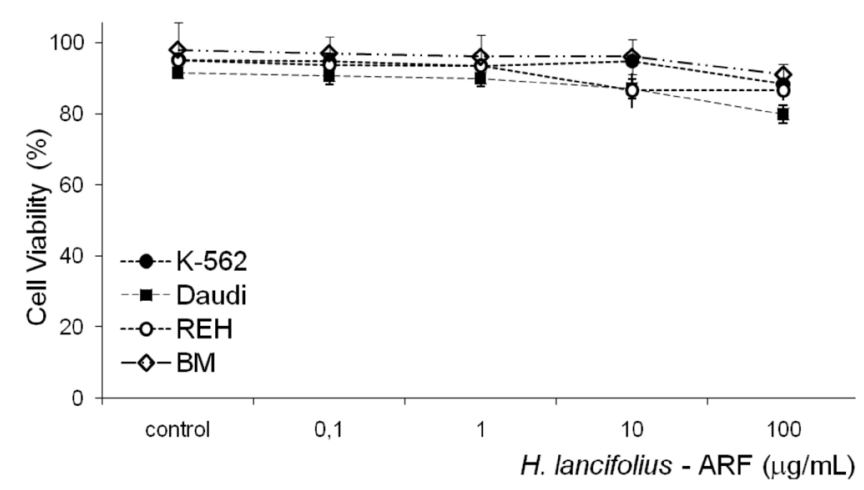

FIGURE 3 - Cytotoxic effects of $H$. lancifolius alkaloid-rich fraction on leukemic and normal cells. Cells in log phase were treated with the indicated doses of ARF for $48 \mathrm{~h}$, at $37^{\circ} \mathrm{C}$. Each point represents the percentage of viable cells \pm EPM recovered after trypan blue exposure from at least 3 experiments, each performed in triplicate. $\left[{ }^{*}\right] p<0.001$.

Because K-562 and Daudi cells are able to generate colonies in soft systems when appropriately stimulated, in order to investigate whether the inhibitory effect would affect the clonogenic response of these cells they were exposed to ARF $(0.1-100 \mu \mathrm{g} / \mathrm{mL})$ for seven days at $37^{\circ} \mathrm{C}$ and $5 \% \mathrm{CO}_{2}$. This resulted in significant concentration-dependent inhibition of colony formation for both cell lines compared to the respective untreated populations (Figure 4).

For K-562 cells, the number of colonies declined from $176.6 \pm 13.3$ (control) to $163.5 \pm 16.8(p=0.025)$, $138.8 \pm 12.1(p \leq 0.05)$, and 105.3 $\pm 2.0(p \leq 0.001)$, respec-

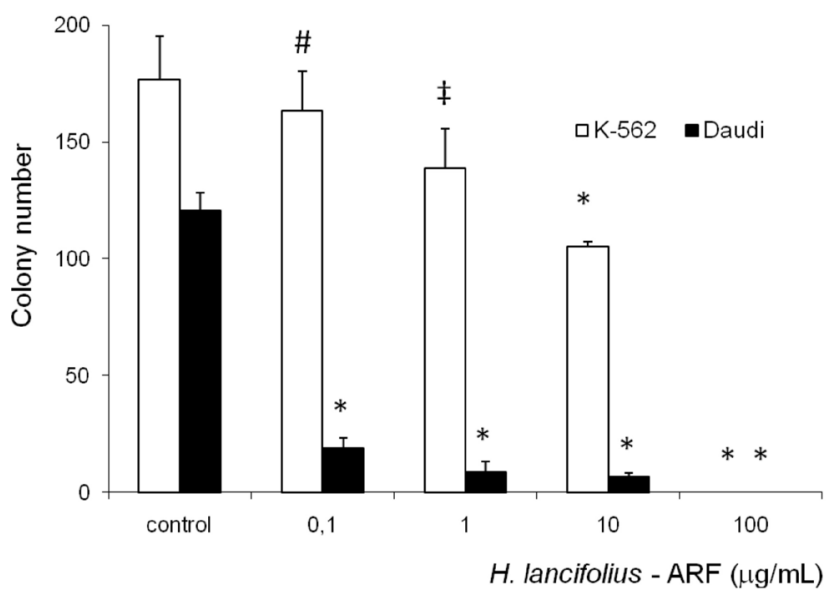

FIGURE 4 - Inhibition of the clonogenic potential of leukemic cells by $H$. lancifolius alkaloid-rich fraction. Exponentially growing K-562 $\left(10^{3} / \mathrm{mL}\right)$ and Daudi cells $\left(10^{4} / \mathrm{mL}\right)$ were continuously exposed to increasing doses of ARF of $H$. lancifolius in soft-growing systems for 7 days at $37^{\circ} \mathrm{C}$ and $5 \%$ $\mathrm{CO}_{2}$, as described in Materials and Methods. Each bar represents the mean \pm EPM of colonies formed, scored under an inverted microscope. [\#] $p=0.025 ;[\dagger] p<0.05 ;\left[{ }^{*}\right] p<0.001$. tively at $0.1,1$ and $10 \mu \mathrm{g} / \mathrm{mL}(\mathrm{n}=3)$. For Daudi cells, the values decreased from $120.5 \pm 7.8$ (control) to $19.0 \pm 4.2$, $9.0 \pm 4.2$, and $7.0 \pm 1.4$ for the same dose range $(p \leq 0.001)$. At $100 \mu \mathrm{g} / \mathrm{mL}$, complete abrogation of colony formation response was observed for both cell lines. It is important to note that, although the number of colonies was affected, their size and morphology did not differ to those of the control experiments.

Cytospun preparations of the cultured cells after induction of differentiation showed no signs of damage or deterioration of either K-562 (Figure 5-A) or Daudi cells (Figure 5-B) but maintenance of their original phenotype, supporting not only the maintenance of the original phenotype but also their integrity. As small population presenting surface blebbing, denser cytoplasm, and nuclear well-delimited masses of various shapes and sizes of chromatin were observed (Figure 5, arrows in panels A and B), further experiments were conducted to clarify whether ARF would affect apoptosis in K-562 (Figure 5-C) and Daudi cells. Flow cytometry analyses showed that less than $15 \%$ of the cells were positively labeled with Annexin-V and 7-AAD, suggesting that ARF does not induce apoptosis or necrosis, respectively, in these cells, confirming cell proliferation blocking.

\section{DISCUSSION}

Particularly as infusions, several plants have been used for the treatment of various diseases since ancient times and have gained recognition as biological response modifiers. A relevant concern is the detection of effects present in these infusions that may interfere with cell division. In this context, plants have been a source of clinically relevant anticancer compounds and nowadays many natural products and derivatives belong to the standard repertoire of cancer chemotherapy (Efferth et al., 2007). As an example, the compound homoharringtonine, isolated from Cephalotaxus species, has recently been reported to be among the most potent members of the antileukemia alkaloids (Quintás-Cardama, Cortes, 2008). Therefore, the development of new agents able to impair leukemic cell growth is required to reduce not only the rate of mortality but also to provide ways for normal hematopoietic recovery.

Indole alkaloids isolated from a variety of medicinal plants have shown anti-leukemic effects (Gan et al., 2006; Zhang et al., 2007). H. lancifolius is a Brazilian native plant that grows widely in several regions around the country and is rich in indole alkaloids. This prompted us to investigate the potential effects of its ARF on the in vitro growth of normal and leukemic cells. 

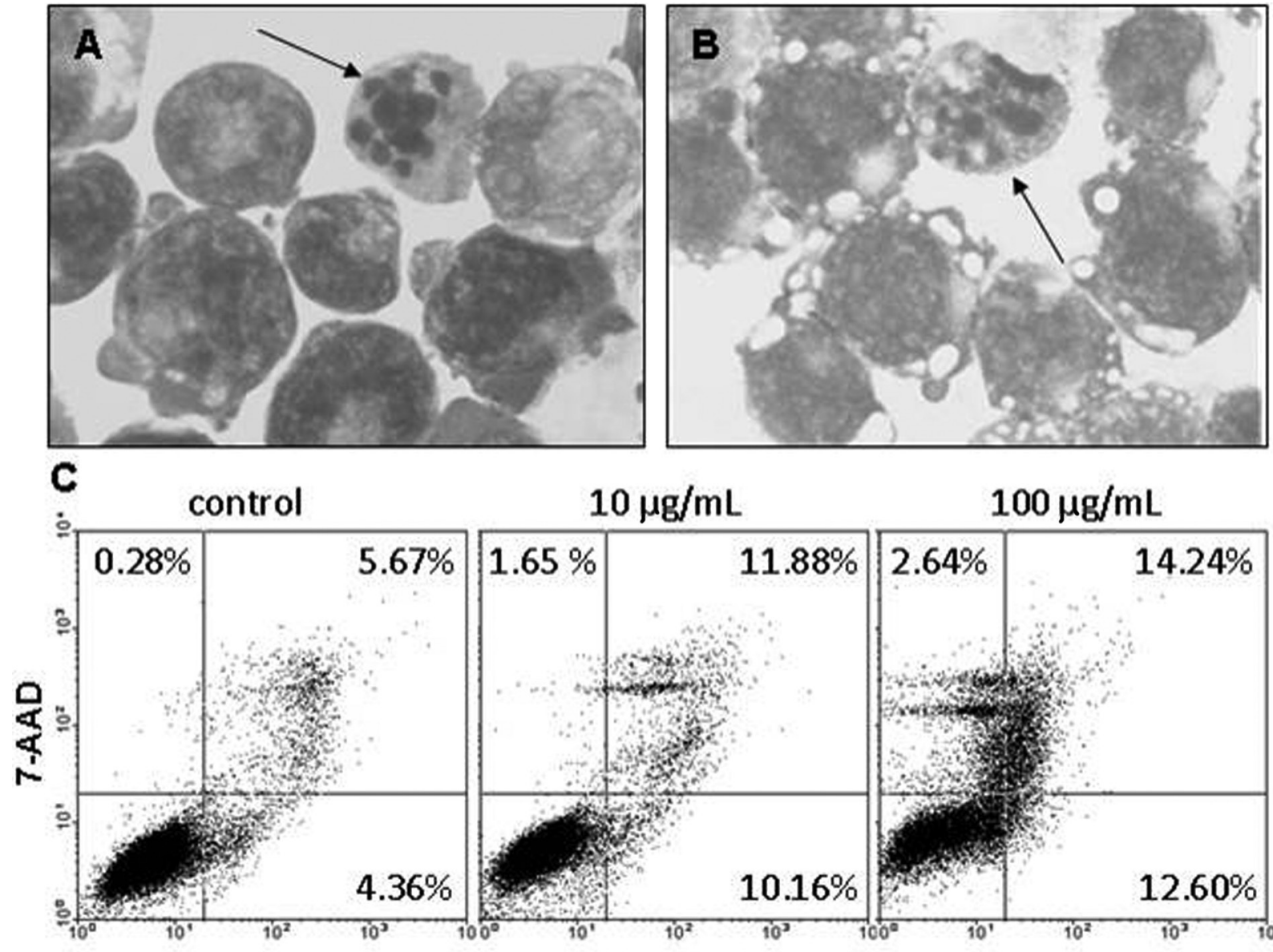

$10 \mu \mathrm{g} / \mathrm{mL}$

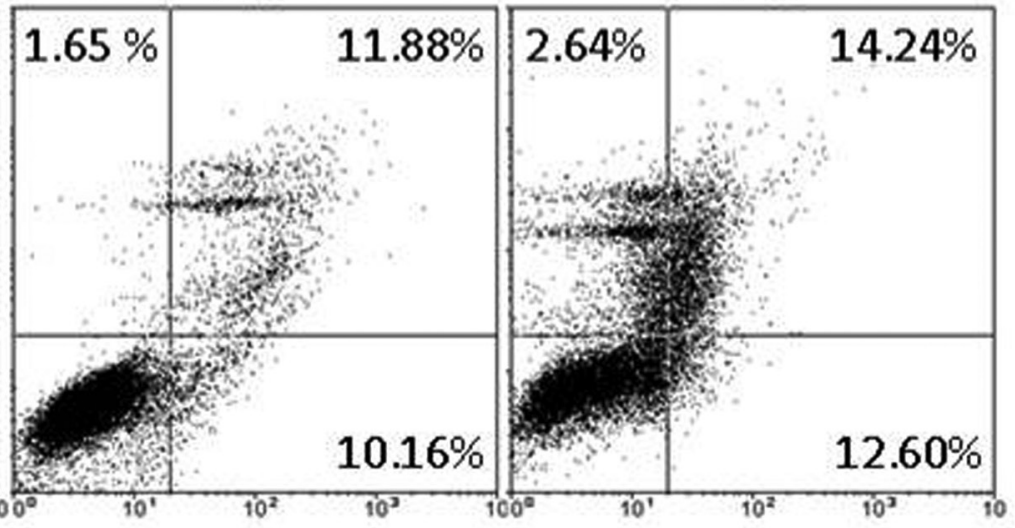

ANNEXINV

FIGURE 5 - Alkaloid-rich fraction of H. lancifolius does not induce apoptosis in leukemic cells. K-562 and Daudi cells plated in RPMI 1640 at $37^{\circ} \mathrm{C}$ for $24 \mathrm{~h}$ were treated with increasing doses $(0.1-100 \mu \mathrm{g} / \mathrm{mL})$ of ARF for $48 \mathrm{~h}$. The morphology of the cultured cells was observed by immersion oil microscopy in cytospin preparations stained with May-Grunwald-Giemsa. The photos depict K-562 (A) and Daudi (B) cells after treatment with $10 \mu \mathrm{g} / \mathrm{mL}$ of ARF. Rare apoptotic figures were observed (arrows). Magnification: $\times 1000$. Panels in C show Annexin V and 7-AAD co-expression on K-562 cells after treatment with ARF, analyzed by flow cytometry.

The proliferation assays showed that all leukemic cell lines included in this study responded to ARF in a similar fashion, independent of their lineage origin, with significant inhibition of their growth. In this context, the most relevant anti-proliferative activity was against REH and Daudi cells, both of lymphoid origin (Klein et al., 1968), followed by the $\mathrm{K}-562$ cell line, which is a myeloid descendant (Lozzio et al., 1981). It is noteworthy that, because many anticancer agents are less cytocidal to quiescent cells than to actively proliferating cells, we only exposed proliferating cells to ARF to assure the effects would not rely upon quiescent cells. Although not proliferating, the leukemic cells were viable as defined by the trypan blue exclusion test. The anti-proliferative activity of ARF was further confirmed using the clonogenic survival assay, in which ARF influenced the frequency of K562 and Daudi colonies, indicating that both short and long exposures to ARF were efficient in suppressing their growth response. Notably, along with proliferation tests, the in vitro colony-forming assays have been used for screening candidate compounds for potential hematotoxicity as it has proven to be a sensitive indicator of toxicity and have greater predictive value than conventional evaluations of peripheral blood cell counts and bone marrow cytology as a test for the hematotoxic potential of certain classes of compounds in humans (Parchment et al., 1993).

One of the factors regulating the population size of a clone of proliferating cells is the induction of a physiological suicide mechanism known as apoptosis, a highly regulated process that occurs as part of differentiation, proliferation and growth of normal and malignant cells. Visualized by light microscopy, exposure of the cell lines included in this study, to increasing doses of ARF for 48 hours did not induce differentiation. However, it did induce morphological changes characteristic of apoptosis but 
only in a small population, which were confirmed by their low incorporation of Annexin-V. Thus, the data suggested that the $H$. lancifolius ARF was promoting a cytostatic rather than cytotoxic effect on these cell lines which was not observed for normal marrow cells.

Ex vivo maintenance and expansion of human primitive hematopoietic cells has been a focus of current research because it potentially involves clinical applications. The standard culture methods for this purpose rely on optimized combinations of cytokines. Although these conditions provide some level of progenitor cell support, they primarily induce proliferation and differentiation, resulting in reduced repopulation capacity. The preliminary results presented in this study showed that the ARF prepared from the barks of $H$. lancifolius was able to inhibit the growth of some leukemic cell lines while preserving normal marrow cells. The anti-leukemic activity observed for ARF was not due to the induction of differentiation or apoptosis. In fact, our data showed that ARF had a significant cytostatic activity on these tumor cell lines.

There are several medicinal plants considered to possess significant anti-cancer activity, which have numerous bioactive compounds that contribute to these beneficial health effects. More recently, evidence is emerging that combinations of phytochemicals may be more effective in the war against cancer than isolated compounds. In fact, combinatorial effects have been observed (de Kok et al., 2008) in which different and complementary modes of actions are involved (Kale et al., 2008; Moon et al., 2006). These activities can be attributed to their ability to interact with basic cellular mechanisms, including interference with membrane and intracellular receptors, modulation of signaling cascades, interaction with the basic enzymes involved in tumor promotion and metastasis, interaction with oncogenes and oncoproteins, and, finally, direct or indirect interactions with nucleic acids and nucleoproteins (Kampa et al., 2007).

Moreover, a variety of strategies are currently being considered for ex vivo elimination of neoplastic cells from autologous bone marrow grafts. The key objective inherent to these strategies is to effectively eliminate neoplastic cells while sparing the normal hematopoietic progenitor cells crucial for engraftment. Therefore, the capacity of the H. lancifolius ARF fraction to preferentially inhibit the cell growth of leukemic cells makes it a candidate for further studies to clarify the mechanisms underlying these effects. This may prove important for ex vivo manipulation of human primitive hematopoietic cells for clinical applications, extending the goal of cancer therapy to eradicating the affected cells (to control the cancer phenotype) while allowing the expansion of the normal hematopoietic population.

\section{ACKNOWLEDGEMENTS}

This study was supported by grant No. 400849/20054 from CNPq, Brazilian Government. C.A.M. Santos and M.P. Lima are grateful to CNPq and CAPES, respectively, for scholarship.

\section{REFERENCES}

BAGGIO, C. H.; OTOFUJI, G. M.; SOUZA, W. M.; SANTOS, C. A. M.; TORRES, L. M.; RIECK, L.; ANDRADEMARQUES, M. C.; MESIA-VELA, S. Gastroprotective mechanisms of indole alkaloids from Himatanthus lancifolius. Planta Med., v.71, p.733-738, 2005.

CASTILLO, D.; AREVALO, J.; HERRERA, F.; RUIZ, C.; ROJAS, R.; RENGIFO, E.; VAISBERG, A.; LOCK, O.; LEMESRE, J. L.; GORNITZKA, H.; SAUVAIN, M. Spirolactone iridoids might be responsible for the antileishmanial activity of a Peruvian traditional remedy made with Himatanthus sucuuba (Apocynaceae). J. Ethnopharmacol., v.112, p.410-414, 2007.

CORREAA, A. D.; BATISTA, R. S.; QUINTAS, L. E. M. Plantas medicinais: do cultivo a terapêutica.: Petrópolis: Ed. Vozes, 1998. p.69.

DE KOK, T. M.; VAN BREDA, S. G.; MANSON, M. M. Mechanisms of combined action of different chemopreventive dietary compounds: a review. Eur. $J$. Nutr., v.47, suppl.2, p.51-59, 2008.

EFFERTH, T.; LI, P. C.; KONKIMALLA, V. S.; KAINA, B. From traditional Chinese medicine to rational cancer therapy. Trends Mol. Med., v.13, p.353-361, 2007.

FRANÇA, O. O.; BROWN, R. T.; SANTOS, C. A. Uleine and demethoxyaspidospermine from the bark of Plumeria lancifolia. Fitoterapia, v.71, p.208-210, 2000.

GAN, L. S.; YANG, S. P.; WU, Y.; DING, J.; YUE, J. M. Terpenoid indole alkaloids from Winchia calophylla. J. Nat. Prod., v.69, p.18-22, 2006.

HUO, X. F.; YU, J.; PENG, H.; DU, Z. W.; LIU, X. L.; MA, Y. N.; ZHANG, X.; ZHANG, Y.; ZHAO, H. L.; ZHANG, J. W. Differential expression changes in K562 cells during the hemin-induced erythroid differentiation and the phorbol myristate acetate (PMA)-induced megakaryocytic differentiation. Mol. Cell Biochem., v.292, p.155-167, 2006. 
KALE, A.; GAWANDE, S.; KOTWAL, S. Cancer phytotherapeutics: role for flavonoids at the cellular level. Phytother. Res., v.22, p.567-577, 2008.

KAMPA, M.; NIFLI, A. P.; NOTAS, G.; CASTANAS, E. Polyphenols and cancer cell growth. Rev. Physiol. Biochem. Pharmacol., v.159, p.79-113, 2007.

KLEIN, E.; KLEIN, G.; NADKARNI, J. S.; NADKARNI, J. J.; WIGZELL, H.; CLIFFORD, P. Surface IgM-kappa specificity on a Burkitt lymphoma cell in vivo and in derived culture lines. Cancer Res., v.28, p.1300-1310, 1968.

LOZZIO, B. B.; LOZZIO, C. B.; BAMBERGER, E. G.; FELIU, A. S. A multipotential leukemia cell line (K-562) of human origin. Proc. Soc. Exp. Biol. Med., v.166, p.546-550, 1981.

MILLIKEN, W. Traditional anti-malarial medicine in Roraima, Brazil. Econ. Botany, v.51, p.212-237, 1997.

MIRANDA, A. L. P.; SILVA, J. R. A.; REZENDE, C. M.; NEVES, J. S.; PARRINI, S. C.; PINHEIRO, M. L. B.; CORDEIRO, M. C.; TAMBORINI, E.; PINTO, A. C. Antiinflammatory and analgesic activities of the latex containing triterpenes from Himatanthus sucuuba. Planta Med., v.66, p.284-286, 2000.

MOON, Y. J.; WANG, X.; MORRIS, M. E. Dietary flavonoids: effects on xenobiotic and carcinogen metabolism. Toxicol. in vitro, v.20, p.187-210, 2006.

NARDIN, J. M.; SOUZA, W. M.; LOPES, J. F.; FLORAO, A.; SANTOS, C. A. M.; WEFFORT-SANTOS, A. M. Effects of Himatanthus lancifolius on human leukocyte chemotaxis and their adhesion to integrins. Planta Med., v.74, p.1253$1258,2008$.

PARCHMENT, R. E.; HUANG, M.; ERICKSON-MILLER, C. L. Roles for in vitro myelotoxicity tests in preclinical drug development and clinical trial planning. Toxicol. Pathol., v.21, p.241-250. 1993.
QUINTÁS-CARDAMA, A.; CORTES, J. Homoharringtonine for the treatment of chronic myelogenous leukemia. Expert Opin. Pharmacother., v.9, p.1029-1037, 2008.

RATTMANN, Y. D.; TERLUK, M. R.; SOUZA, W. M.; SANTOS, C. A. M.; BIAVATTI, M. W.; TORRES, L. B.; MESIA-VELA, S.; RIECK, L.; SILVA-SANTOS, J. E.; MARQUES, M. C. Effects of alkaloids of Himatanthus lancifolius (Muell. Arg.) Woodson, Apocynaceae, on smooth muscle responsiveness. J. Ethnopharmacol., v.100, p.268-275, 2005.

SANDLUND, J. T.; NECKERS, L. M.; SCHNELLER, H. E.; WOODRUFF, L. S.; MAGRATH, I. T. Theophylline induced differentiation provides direct evidence for the deregulation of c-myc in Burkitt's lymphoma and suggests participation of immunoglobulin enhancer sequences. Cancer Res., v.53, p.127-132, 1993.

SANTOS, R. A. Pharmacopéia dos Estados Unidos do Brasil. São Paulo: Editora Nacional, 1926. p.56-57.

SOUZA, W. M.; STINGHEN, A. E.; SANTOS, C. A. M. Antimicrobial activity of alkaloidal fraction from barks of Himatanthus lancifolius. Fitoterapia, v.75, p.750-753, 2004.

VANDERLEI, M. F.; SOUZABRITO, A. R. M. Spasmodic effects of Himatanthus phagedaenica (Mart) Woodson. Braz. J. Med. Biol. Res., v.19, p.A573, 1986.

ZHANG, H.; WANG, X. N.; LIN, L. P.; DING, J.; YUE, J. M. Indole alkaloids from three species of the Ervatamia genus: E. officinalis, E. divaricata, and E. divaricata Gouyahua. J. Nat. Prod., v.70, p.54-59, 2007.

Received for publication on $28^{\text {th }}$ April 2009 Accepted for publication on $23^{\text {th }}$ August 2009 